African Crop Science Journal by African Crop Science Society is licensed under a Creative Commons Attribution 3.0 Uganda License. Based on a work at www.ajol.info/ and www.bioline.org.br/cs DOI: http://dx.doi.org/10.4314/acsj.v25i1.8S

\title{
COLLECTIVE MARKET PARTICIPATION FOR IMPROVED INCOME AMONG SMALLHOLDER FARMING HOUSEHOLDS: A CASE OF BALAKA INNOVATION PLATFORM IN MALAWI
}

\author{
N. MANGO, C. MAKATE, M. LUNDY ${ }^{1}$, S. SIZIBA ${ }^{2}$, K. NYIKAHADZOI ${ }^{3}$ and A.O. FATUNBI ${ }^{4}$ \\ International Centre for Tropical Agriculture (CIAT), P.O. Box MP 228, Mt. Pleasant, Harare, Zimbabwe \\ ${ }^{1}$ International Centre for Tropical Agricultural (CIAT), Apartado Aereo 6713, Cali, Colombia \\ ${ }^{2}$ Department of agricultural Economics, University of Zimbabwe, P.O. Box MP 167, Mt. Pleasant, \\ Harare, Zimbabwe \\ ${ }^{3}$ School of Social Work, University of Zimbabwe, P.O. Box MP 167, Mt. Pleasant, Harare, Zimbabwe \\ ${ }^{4}$ Visioning \& Knowledge Management, Forum for Agricultural Research in Africa (FARA), PMB 173, \\ Cantonment, 12 Anmeda Street Roman Ridge, Accra Ghana \\ Corresponding author: nelsonmango16@gmail.com
}

\begin{abstract}
Collective market participation can reduce transaction costs and information asymmetries, which can build up market power. The objective of this study was to evaluate decisions to participate in collective marketing and its effect on household income among smallholder farmers in an Innovation Platform (IP). This study targeted the Balaka IP in Malawi. Collective marketing identified as critical for improving households' incomes, is one of the activities that Balaka Innovation Platform has been addressing since its formation in 2009. The study involved a sample of 115 randomly selected households from Balaka Innovation Platform. The odds of participating in collective marketing by smallholder farm households in Balaka was significantly influenced by gender, education level, access to social capital through membership in farmer groups that form the Innovation Platform, farming experience, adoption/practice of conservation agriculture and possession of assets e.g. cellphone and bicycle. Moreover, results indicate that functions of IPs such as organising farmers to market collectively, promoting crop diversification, improved extension service, credit access through linkages to microfinance, communication and market linkages, positively influence income. Thus participation in multi-stakeholder IP activities highly influences collective marketing, which in turn impacts positively on smallholder farming households' income.
\end{abstract}

Key Words: Cellphone, collective marketing, linkages, multi-stakeholder

\section{RÉSUMÉ}

La participation collective au marché peut réduire les coûts de transaction et les assymétries d'information; lesquelles peuvent constituer un pouvoir du marché. L'objectif de cette étude était d'évaluer les décisions à participer à la commercialisation collective et leur effet sur le revenu des ménages entre les petits exploitants agricoles dans une Plate-forme d'Innovation (IP). Cette étude s'est focalisée sur le Balaka IP au Malawi. La commercialisation collective identifiée comme essentielle pour l'amélioration des revenus de ménages, est une des activités que la Plate-forme d'Innovation de Balaka a toujours abordé depuis sa mise en place en 2009. Cette étude a utilisé un échantillon de 115 ménages aléatoirement selectés dans la Plate-forme d'Innovation de Balaka. Les chances de participation des petits exploitants agricoles à la commercialisation collective au Balaka était significativement influencées par le genre, le niveau d'éducation, l'accès au capital social à travers les groupements de producteurs qui forment la Plate-forme d'Innovation, l'expérience agricole, l'adoption/la pratique de l'agriculture conservative et la possession d'actifs eg. téléphone cellulaire et bicyclette. De plus, les résultats montrent que les 
fonctions des IPs telles que: organiser les agricultures à commercialiser collectivement, promouvoir la diversification de culture, le service amélioré de vulgarisation, l'accès au credit en liaison avec la microfinance, la communication et les liens commerciaux, influencent posistivement le revenu. Ainsi, la participation multipartite aux activités de l'IP influence la commercialisation collective, qui en conséquence impacte positvement sur le revenu des petits exploitants agricoles.

Mots Clés: Commercialisation collective, multipartite, liens, téléphone cellulaire

\section{INTRODUCTION}

Most of the developing world still directly or indirectly depends on agriculture for their livelihoods, mostly as small-scale farmers. Efforts to uplift this world's agricultural development in the past, targeted building farmer's production capabilities (Fischer and Qaim, 2012). Nowadays, improving farmers' access to markets has become a key element in strategies to promote rural development and enhance farmers' income (Fischer and Qaim, 2012). In order to succeed in improving market participation and improving income, agricultural development programmes have to address the multiple market failures that smallholder farmers suffer from (Jayne et al., 2010).

In the 1980's African governments were affected by structural adjustment programs (SAPs) (FAC, 2009). These adjustment programmes led to market liberalisation and reduction of government involvement in some agricultural activities (Abaru et al., 2006). Changes due to the SAPs brought gaps in the roles that were previously performed by the government ministries such as agricultural extension (FAC, 2009). Consequences of these gaps were exposure of farmers to food insecurity, poor access to markets and market information, poor incomes from agricultural activities, poor access to credit and extension services (Kydd and Dorward, 2004).

Smallholder farmers in particular, now face various constraints that impede them from taking full advantage of marketing opportunities. The constraints in accessing available markets for maximum benefits include poor access to information, poor market and road infrastructure, and smallholder farmers, high transaction costs that often reduce their incentives for market participation (Key et al., 2000; Barrett, 2008). This is true for both input and output markets. Furthermore, they have small land holdings with few assets, and often have limited access to services, including effective extension and credit, which happen to be important preconditions for improving production systems (Reardon et al., 2009). Collective marketing of agricultural commodities has recently been one of the recent developments believed to improve benefits of the smallholder farmer (Nyikahadzoi et al., 2010).

Farmer groups in marketing are avenues to reduce transaction costs (Valentinov, 2007; Markelova et al., 2009). They can be oriented towards improving production, marketing or livelihoods in general, sometimes serving more than one purpose (Bernard et al., 2008; Bernard and Seyoum, 2009; Francesconi and Heerink, 2011). While there is evidence indicating that smallholder farmers are unable to compete in high-value markets, there are various examples where they successfully participate through collective action and institutional support (Narrod et al., 2009). For example, Holloway et al. (2000) demonstrated that for the dairy sector in Ethiopia, cooperative marketing for small producers reduces transaction costs. In Kenya, Ethiopia and Zambia, green bean growers organised in farmer groups were able to enter markets in Europe (Okello et al., 2007).

The objective of this paper was to better understand what drives collective action in 
marketing among smallholder farmers in Balaka and through what mechanism the potential benefits of collective marketing emerge.

\section{METHODOLOGY}

Data collection. This study used crosssectional household data using a questionnaire with semi structured and structured questions. The survey gathered data from Balaka IP in Malawi. Random sampling was used to select 5 villages in Balaka district, from which the sample of 115 smallholder farmers was selected randomly. Resident district agricultural extension officers from the 5 villages provided lists of households. The survey collected information on household composition and characteristics, cereal and legume crop production, household market participation, access to infrastructure, household incomes, ownership of land and non-land assets, crop diversification, group membership, conservation agriculture adoption and practice, livestock ownership and access to agricultural inputs on credit and many other socioeconomic variables.

Balaka Innovation Platform. Balaka IP was formed in 2009 with the aim of addressing farmer problems. An IP comprises of a group of individuals with different backgrounds and interest: farmers, traders, processors, researchers, government officials, etc. The members come together to diagnose problems, identify opportunities and find ways to achieve their goals. They may design and implement activities as a platform, or coordinate activities by individual members.

The Balaka IP was initiated by the International Centre for Tropical Agriculture (CIAT) in 2009. As a research organisation, CIAT identified the broad focus area of the IP. Initially, it identified stakeholders, brought them together and convened meetings. Day to day facilitation of the platform was done through the government extension agents. The main problems which were meant to be addressed by the platform in Balaka include; low productivity, lack of input and output markets, low incomes, and poverty in general.

Through multi-stakeholder dialogue the platform proposed activities meant to improve livelihoods of participants. Some of the activities included conservation agriculture adoption, crop diversification, improved communication through the platform, linking farmers to microfinance institutions, collective market participation, joining farmer groups organised by the platform and various other activities. The main aim was to improve household income and food security.

Results were meant to be achieved through the strength of the platform. The platform is considered powerful as it leads to better informed decisions, it contributes to capacity development, it makes innovative research possible and more importantly it can enhance impact. It, therefore, means that farmers can improve their agricultural productivity and profitability and improve how they manage natural resources. More importantly farmers can increase their income and reduce poverty.

Conceptual framework. The study developed a simple model of collective market participation for farmers in Balaka district of Malawi. It considered a dummy variable for collective market participation with two values, 1 if the farmer sold collectively, and 0 for otherwise. If a farmer decides to sell individually the study assigned a value of zero, the same to those who did not sell completely. Each farmer considered was a utility maximiser that is, derives some utility from either selling or not selling their crops collectively. If a farmer decided not to sell collectively the study assumed that there was some utility associated with such a move. Without loss of generality, the study normalised this utility associated with not selling collectively to zero. Collective market participation in this paper was measured in this way; if a farmer sold at least one of his or her crops collectively, we considered him/her as 
a collective market participant; and any other scenario we considered otherwise.

Econometric model. The decision to sell collectively was modelled in a simple logistic regression and reported are the odds ratios. The smallholder farmer's behavior towards collective market participation is described by the following Equations numbered 1 - 4 .

Probability of an event $=\mathrm{P}(\mathrm{Y}, 1$, if the smallholder farmer sells collectively and 0 , otherwise) Equation 1

Let $\mathrm{X}_{\mathrm{i}}$ represent a set of parameters including socioeconomic, farming, institutional factors, and other household specific characteristics which influence the collective marketing decisions of the individual farmer. We also assume that $\mathrm{Z}_{\mathrm{i}}$ is an indirectly utility derived from selling farm produce collectively which is a linear function of $k$ explanatory variables $(\mathrm{X})$, and is expressed as:

$$
Z_{\mathrm{i}}=\beta_{0}+\sum_{i=1}^{n} \beta_{i} X_{k i}+\varepsilon_{i} \ldots \ldots . . \text { Equation } 2
$$

Where:

$\beta_{0}$ is the intercept term, and, $\beta_{l}, \beta_{2}, \beta_{3} \ldots \ldots, \beta_{i}$ are the coefficients associated with each of the $k$ explanatory variables $\left(\mathrm{X}_{1}, \mathrm{X}_{2}, \mathrm{X}_{3}, \ldots, \mathrm{X}_{\mathrm{ki}}\right)$ and $\varepsilon_{i}$ is an error term that follows a logistic distribution. The $\mathrm{X}$ vector of variables explain collective market participation by the smallholder farmer, i.e. it explains the likelihood of participation in the market collectively with others by the individual $\left(i_{\text {th }}\right)$ farmer (Table 1$)$.

Since $\mathrm{P}_{\mathrm{i}}$, the probability of participation is not observable; we asked the farmers whether they sold collectively or not in any of their previous season crop output. The farmers sampled were asked a specific question on collective market participation, whether they sold any of their produce collectively with yes or no responses.

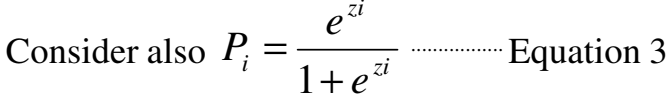

Where:

$\mathrm{P}_{i}$ denotes the probability of the $i^{\text {th }}$ farmer's participation decision, and $\left(1-\mathrm{P}_{\mathrm{i}}\right)$ is the probability of not participating collectively in the market. The odds of participation $(\mathrm{Y}=1)$ vs non-participation $(\mathrm{Y}=0)$ to be used can be defined as the ratio of the probability that a farmer sells collectively $\left(\mathrm{P}_{\mathrm{i}}\right)$ to the probability of not selling collectively $\left(1-\mathrm{P}_{\mathrm{i}}\right)$, namely odds $=P_{i} /\left(1-P_{i}\right)($ Long, 1997). By taking the natural Logarithms, we get the prediction equation for the individual farmer:

$\operatorname{Ln}\left(\frac{P_{i}}{1-P_{i}}\right)=\beta_{0}+\sum_{i=1}^{n} \beta_{i} X_{k i}=Z_{i}$

Equation 4

Where $Z_{i}$ is also referred to as the odds ratio in favour of collective market participation or in other words the unobserved probability that the farmer either sells collectively or not sells collectively.

A logit model for collective market participation with collectivmktng, Age1, hh_sex, edu, labour, mktinfo, transprtaccess, Extensionfreq, Group, Expfarming, Distmkt, Bicycle, Cellphone, and CA_Practice as predictor variables was then run. Table 1 presents a description of the explanatory variables. Economic theory on market participation and the factors likely to influence market participation decisions was used in selecting the covariates used in the logistic regression model.

Choice of variables to explain variability in collective market participation was guided mainly by previous studies on collective action in smallholder farming, researchers' knowledge of the Balaka innovation platform, and collective action literature and intuition. 
TABLE 1. Explanatory variables selected to explain collective market participation and their posited signs for the Balaka IP in Malawi

\begin{tabular}{lc}
\hline Variable $\quad$ Variable description & $\begin{array}{c}\text { Posited } \\
\text { sign }(+/-)\end{array}$ \\
\hline
\end{tabular}

\begin{tabular}{|c|c|c|}
\hline Age1 & Age of farmer in years & - \\
\hline hh_sex & Gender of household head ( $1=$ male $)$ & $+/-$ \\
\hline edu & Education level of household head & + \\
\hline 1(no education) & No education & - \\
\hline 2(primary) & primary & + \\
\hline 3(secondary) & secondary & + \\
\hline 4(vocational) & Vocational training & + \\
\hline 5(university) & University & + \\
\hline labour & Number of household members who provide labor & + \\
\hline mktinfo & Market information access, 1 if yes, and 0 if no access & + \\
\hline transprtaccess & $\begin{array}{l}\text { Transport information access } 1 \text { if farmer have access to any form of transport } \\
\text { information, and } 0 \text { if no access }\end{array}$ & + \\
\hline Extensionfreq & Frequency of extension visits & + \\
\hline Group & $\begin{array}{l}\text { Group membership (proxy for access to social capital) } 1 \text { farmers belongs to a } \\
\text { farmer group, } 0 \text { if no }\end{array}$ & + \\
\hline Expfarming & Natural log of years of farming experience & $+/-$ \\
\hline Distmkt & Distance to the nearest input/output market & - \\
\hline Bicycle & Ownership of a bicycle 1 yes, 0 no & + \\
\hline Cellphone & Dummy for possession of cell phone 1 if yes, 0 if no & $+/-$ \\
\hline CA_Practice & Dummy for Conservation Agriculture practice 1 practice $\mathrm{CA}, 0$ not practicing CA & + \\
\hline
\end{tabular}

Some of the studies that were used to guide selection of explanatory variables of collective action included Bernard and Spielman (2009), Francesconi and Heerink (2011), Adong et al. (2012) and Yang and Liu (2012). The study mainly chose the mentioned authors' work to guide variable selection because of their focus on collective action studies and also on smallholder farming. In addition, the study used their findings, conclusions and other collective action literature in hypothesizing direction of influence of chosen variables on collective market participation.

Impact of collective marketing on income. To conceptualise and measure the impact of collective market participation, the study adopted the potential outcomes framework following the work of Rosenbaum and Rubin (1983), Angrist et al. (1996), and Heckman and Vytlacil (2005). According to this framework impact (treatment effect) can be defined as the outcome for exposure (participation) minus the outcome for nonexposure (non-participation)-( $\left.\mathrm{Y}_{1}-\mathrm{Y}_{0}\right)$. In our specific case it is the difference in income between collective market participants and non-collective participants.

Due to the fact that it is impossible to observe both an outcome and counterfactuals for the same individual, this approach relies on different individuals to estimate treatment effect. Because of the possibility of selection biases, participating farmers and nonparticipating farmers tend to be systematically different sub-samples. The inherent challenge 
of impact evaluation is, therefore that of isolating the effect of the treatment from other factors and potential selection biases (Khandker et al., 2010).

One of the often used means of dealing with selection bias and achieve statistically comparable groups, utilises the two key assumptions of conditional independence and overlap. Conditional independence assumption states that given a set of observable covariates $X$ that are not affected by treatment; potential outcomes $\mathrm{Y}$ are independent of treatment assignment $T$. This means that $X$ must account for factors influencing exposure such that after controlling for those, the effect of collective market participation can be obtained free of selection bias. The overlap assumption requires that for all possible values of $\mathrm{X}$, there are both treated and untreated units. Rosenbaum and Rubin (1983) term conditional independency overlap as 'strong ignorability'.

In this study, the average treatment effect (ATT) was estimated using the nearest Neighbour Matching approach. This approach imputes the missing potential outcomes for the untreated group using average outcomes for individuals with similar observed characteristics, based on covariates X (Table $1)$.

\section{RESULTS AND DISCUSSION}

Descriptive statistics. Table 2 presents information on farmers' collective market participation status in some selected socioeconomic attributes of households in the Balaka IP in Malawi. Mean farm income of participants was found to be US\$ 428.68 and 337.33 for non-participants, but not significantly different $(P>0.05)$. Notable differences between participants and non-participants were only found in farming experience and labour. Nonmarket participants had more years of farming experiences at the time of the survey. Noncollective market participants had (21.94) mean. Collective market participants had more labour personnel fit to work in their fields with a mean of 3.33 compared to 2.84 for nonmarket participants.

For all other household characteristics, head age, male, family size, conservation agriculture practice, crop diversification, credit access, extension service reception frequency, market access, transport access, distance to market,

TABLE 2. Socioeconomic comparison of collective market participants and non-market participation in Balaka IP in Malawi

\begin{tabular}{lrrr}
\hline Variable & Participants & Non-participants & t-test \\
\hline Farm Income (US\$) & 427.68 & 337.33 & 0.301 \\
Age & 48.10 & 50.83 & 0.328 \\
Farming experience & 17.24 & 21.94 & $0.039^{* *}$ \\
Male (\%) & 0.65 & 0.75 & 0.285 \\
Family size & 5.27 & 4.95 & 0.406 \\
Conservation Agriculture Practice (\%) & 0.85 & 0.94 & 0.117 \\
Crop diversification & 0.73 & 0.76 & 0.705 \\
Credit (\%) & 0.88 & 0.90 & 0.728 \\
Extension frequency & 2.88 & 2.92 & 0.945 \\
Labour & 3.33 & 2.84 & $0.074 *$ \\
Market access (\%) & 2.35 & 2.76 & 0.256 \\
Transport access (\%) & 0.44 & 0.40 & 0.626 \\
Distance to main input/output market & 4.07 & 4.63 & 0.114 \\
Cellphone (\%) & 0.69 & 0.78 & 0.303 \\
Bicycle (\%) & 0.77 & 0.68 & 0.306 \\
\hline
\end{tabular}

*significant at 10\%; **significant at 5\%; ***significant at $1 \%$ 
possession of mobile phones and bicycles were not significantly different.

Collective market participation. The results of the logistic model are presented in Table 3. The number of observations used in the model are 115 . Prob $>$ Chi $2=0.0010^{* * *}$; and a pseudo R2 of $23.84 \%$, showing that the model was valid and estimates fitted very well the data at an acceptable level.

Table 3 presents standard errors (S.E), Odds ratios and the p-values. Odds ratios show the predicted change in odds for a unit increase in the corresponding explanatory variable. These estimates provide information on the relationship between significant explanatory variables and their influence on collective marketing adoption within the study area, where the dependent variable is on the logit scale. Significant variables in the logistic model were gender, primary education, labor, market information access, group membership, farming experience, ownership of a bicycle and practice of conservation agriculture.

Gender of household was used to capture differences in tastes and preferences for men and women in farmer collective market participation. Male headed households were expected to have relatively higher chances of participating collectively in the market. Female headed households are expected to have higher chances of joining farmer groups, but less inclined to market participation. Gender of household head from the model was significant in influencing collective marketing participation $(\mathrm{P}<0.01)$. The odds of participating collectively in the market in Balaka were 0.309 times larger for men compared to women. Results imply that collective market participation was less likely to happen if the household head was male compared to where the household head was a woman. The result contradicted our

TABLE 3. Variables influencing collective market participation in Balaka Innovation Platform in Malawi

\begin{tabular}{lllll}
\hline Variable & Variable description & $\begin{array}{l}\text { Odds } \\
\text { Ratio }\end{array}$ & Std. Err. & P-value \\
& & & & \\
collectivmktng & Dummy variable for collective marketing & & \\
Age1 & Age of farmer in years & 1.525 & 1.4642 & 0.660 \\
hh_sex & Gender of household head & 0.309 & 0.1898 & $0.056^{*}$ \\
& & & & \\
edu & Education level of household head & & & \\
& & & & \\
1(no education) & No education & 4.557 & 5.4592 & 0.206 \\
2(primary) & primary & 9.909 & 13.5519 & $0.094^{*}$ \\
4(vocational) & Vocational training & 1.414 & 2.3769 & 0.837 \\
& & & & \\
labour & Number of household members who provide labor & 1.694 & 0.3197 & $0.005^{* * *}$ \\
mktinfo & Market information access & 1.96 & 0.1028 & $0.002^{* * *}$ \\
transprtaccess & Transport information access & 2.204 & 1.1132 & 0.118 \\
Extensionfreq & Frequency of extension visits & 0.987 & 0.0903 & 0.890 \\
Group & Group membership (proxy for access to social capital) & 4.869 & 3.8256 & $0.044^{* *}$ \\
Expfarming & Natural log of years of farming experience & 0.522 & 0.2037 & $0.096^{*}$ \\
Distmkt & Distance to the nearest input/output market & 0.894 & 0.1129 & 0.375 \\
Bicycle & Ownership of a bicycle & 4.166 & 2.6979 & $0.028^{* *}$ \\
Cellphone & Dummy for possession of cell phone & 1.91 & 0.1334 & $0.018^{* *}$ \\
CA_Practice & Dummy for Conservation Agriculture practice & 1.77 & 0.1556 & $0.049^{* *}$ \\
_cons & Constant & 0.288 & 1.0561 & 0.734 \\
\hline
\end{tabular}

$*$ Significant at $10 \%$; * Significant at $5 \%$; ** Significant at $1 \% ; \mathrm{N}=115$; Pseudo $\mathrm{R}^{2}=23.84 \%$; Prob $>\mathrm{Chi}^{2}=$ $0.0010^{* * *}$ 
expectation that men would be more likely to participate in the market collectively. Results also contradicted those of Mukundi et al. (2013), but were consistent with those of Musyoki et al. (2013). Exploring possible constraints hindering equal participation chances of women farmers could improve overall collective market participation in Balaka IP. Possibly, less chances of women adopting collective market participation observed in Balaka IP could be as a result of lack of resources and power to effectively make the crucial collective market participation decisions.

The results also showed that collective market participation was 9.9 times likely to happen when the household head had at least primary education (Table 3 ). This result highlights the importance of primary education in the studied area. About $69.57 \%$ of the farmers in the IP had primary education. Usually, education level of the household is used as a proxy for human capital endowment. Education is, therefore expected to have a positive effect on participation in commodity markets. The result confirms that with primary education, farmers' ability to utilise market information is enhanced; which lowers transaction costs and thereby make collective market participation worthwhile.

Results are consistent with that of Olwande and Mathenge (2010) who found out that education was an important determinant of market participation and concluded that educating farmers can improve collective market participation rates amongst rural households. We, therefore, conclude that education is a key determinant of collective market participation in Balaka IP. Households need at least primary education to effectively commit themselves in collective marketing.

One of the significant variables is household labour. Results show that a unit increase in household labour increased the odds of collective market participation by $69.4 \%$. The result was expected because a large labour force is expected to have a positive impact on collective market participation, if the collaborating households provide labour efficiently. In collective market participation; labour is demanded as producers intending to sell collectively have to carry their output to a common warehouse or place in preparation to sell their output to the market of choice. Results are consistent with those of Alene et al. (2008) and Mathenge et al. (2010). Consistency of our results with other researchers' findings confirm that labour is an important determinant of collective market participation in smallholder farming.

With access to market information, smallholder farmers can weigh the pros and cons of available market options, and ways of approaching them. The results confirm that the odds of smallholder farmers marketing their produce collectively were 1.96 times likely among farmers with access to market information.

In line with market information, ownership of a mobile phone also increased the odds of collective market participation with farmers who own a mobile phone having odds of market participation that are 1.91 times higher compared to those without (Table 3). With a mobile phone farmers searched for relevant information from various sources, and this encouraged participation in commodity markets.

Farmers who had price information prior to marketing tended to be more informed on how to sell and the quantities than those without market information. This finding is consistent with economic theory by Key et al. (2000) and Alene et al. (2008), who found a relationship with price information and market participation. The result, therefore, confirms that access to information, market information in particular, is a crucial determinant of collective market participation. Smallholder farmers need to have access to marketing information for them to firmly decide on whether to participate or not. Access to information can help them to conceive the potential benefits of collective market participation better with aces to information than without. 
Group membership in this study was used as proxy for access to social capital. The assumption was that with access to social capital, a farmer could benefit from other farmers' experiences, and from indigenous technical knowledge from group members. Group membership is expected to have a positive effect on household market participation. Results from our analysis reveal that the odds of marketing produce collectively are 4.9 times more likely for farmers with access to social capital compared to those without access. A possible explanation is that with group membership, farmers can obtain market information easily, i.e. they can get what the market demands in terms of quantities and this can reduce transaction costs associated with collective marketing.

Results are consistent with that of Jagwe et al. (2010) and Fischer and Qaim (2012) who argue that participation in farmer organisations, can reduce transactions costs associated with smallholder agriculture. In addition, group membership in farmer organisations can increase household's access to market information necessary for their decision making.

Farming experience was also a predictor variable selected to explain collective market participation. From the model, the variable was significant $(\mathrm{P}<0.05)$. Farming experience had a positive influence on likelihood of farmer to approach commodity markets collectively with other farmers. The result was expected since an increase in farming experience is associated with improved market participation in this case collective market participation. In the lifecycle of a farmer, a point of decreasing marginal labour productivity is anticipated, whereby an increase in farming experience is expected to be negatively associated with market participation; hence, natural log of farming experience was used to account for the effect of life cycle on collective market participation. Results are consistent with those of Martey et al. (2012), who pointed out that experienced households were able to take better production decisions and have greater contracts which allow trading opportunities to be discovered at lower costs.

Bicycles were one of the common modes of transport for the rural people in Balaka district. They played a very important role in transporting commodities from the rural homes to nearby markets (Table 3). The odds of collective market participation were 4.2 times more likely for households who owned a bicycle compared to those without. This is probably because ownership of a functional bicycle eased transportation of produce for farmers and moreover, transaction costs in collective marketing process were reduced and, hence, encouraging collective market participation.

Conservation agriculture (CA) was a common practice in Balaka IP. CA practice was also a predictor variable selected to explain collective market participation (Table 3). Results indicate that CA had significant influence on collective market participation decisions in Balaka. This can be explained by the fact that the biophysical transformations that are occasioned by practicing conservation agriculture are expected to result in sustained increase in crop yields (Erenstein, 1999). More so, crop rotations reduce pest attack and improve soil fertility which can be expected to improve crop productivity. Minimum soil disturbance also improves organic matter content is why CA farmers can be considered more likely to produce surpluses than their non-CA counterparts. Moreover, access to better agronomic practices and marketing strategies from CA promoters in the district can also explain why CA adopters were more likely to adopt collective market participation when compared to their counterparts.

Distance to the nearest market, transport information access, extension reception frequency and age were not significant in explaining collective market participation.

Impact on income. Table 4 shows the estimated impact of collective market 
TABLE 4. Impact of collective market participation on agricultural income in the Balaka IP in Malawi

\begin{tabular}{lcc}
\hline Variables & NNM & Agricultural income (US\$) \\
\hline Average treatment effect & $144.15^{*}(110.014)$ & \\
Mean of outcome variable & & \\
Collective market participants & & \\
Non-collective participants & 427.68 \\
\hline
\end{tabular}

*Significant at $10 \%$ level. Standard error for the ATT is given in parentheses. NNM = nearest neighbor matching method. There were 83 observations shown made up of 52 collective participants and 31 non-collective participants

participation on farm income. The study utilised the propensity score matching method based on matched observations to isolate the effect of adopting collective market participation on farm income. The results from our empirical analysis shows that, after controlling for farmer socioeconomic characteristics (Table 1), adoption of collective market participation was associated with a significant improvement in farm income. Precisely, the nearest neighbor matching results show that the ATT was US\$ $144.15(\mathrm{P}<0.1)$ on farm income. In other words, farmers who adopted collective market participation in the chosen year/harvest season, increased their agricultural income by US $\$$ $144.15(\mathrm{P}<0.1)$ per growing season.

The result could be explained by the fact that collective market participation improves bargaining power of farmers as sellers on the market, and, hence, they are likely to get higher prices for their produce collectively than as individuals. The result is in line with findings of other authors on the impact of collective market participation. Johnson and Berdegue (2004) noted that cooperating can help farmers negotiate better prices for inputs and outputs. Farmers are able to negotiate for better input and output prices on the market which then improves their farm income. Moreover, Alene et al. (2008), Jagwe et al. (2010) and other market economists revealed that access to input and output markets reduce transaction costs which, therefore, improves the marketing margins for farmers.

\section{ACKNOWLEDGEMENT}

We gratefully acknowledge research funding from the Forum of Agricultural Research in Africa (FARA). We also thank all reviewers for their comments and suggestions on earlier drafts of this article. Special thanks to the enumerators and farmers who took off their time to respond to our questions.

\section{REFERENCES}

Abaru, M.B., Nyakuni, A. and Shone, G. 2006. Strengthening farmers' organizations. The experience of RELMA and ULAMP. Working paper No 23 World Agro-forestry Centre, Nairobi, Kenya.

Adong, A., Mwaura, F. and Okoboji, G. 2012. What factors determine membership to farmer groups in Uganda? Evidence from the Uganda Census of Agriculture 2008/9. Research series No 98. Economic Policy Research Centre, Kampala, Uganda.

Alene, A. D., Manyong, V. M., Omanya, G., Mignouna, H. D., Bokanga, M. and Odhiambo, G. 2008. Smallholder market participation under transactions costs: Maize supply and fertilizer demand in Kenya. Food Policy 33(4):318-328.

Angrist, J. D., Imben, G. W. and Rubin, D. B. 1996. Identification and causal effects using instrumental variables. Journal of the American Statistics Association 91: 444455. 
Barrett, C. B. 2008. Smallholder market participation: Concepts and evidence from eastern and southern Africa. Food Policy 33(4):299-317.

Bernard, T. and Seyoum, T. A. 2009. Returns to scope? Smallholder commercialization through multipurpose cooperatives in Ethiopia. Contributed paper in the International Association of Agricultural Economists conference, August 16-22, 2009. Beijing, China.

Bernard, T. and Spielman, D. 2009. Reaching the rural poor through rural producer organizations? A study of agricultural marketing cooperatives in Ethiopia. Food Policy 34:60-69.

Bernard, T., Seyoum T.A. and Gabre-Madhin, E. 2008. Impact of cooperatives on smallholders' commercialization behavior: Evidence from Ethiopia. Agricultural Economics 39(2): 147-161.

Erenstein, O.C. 1999. The economics of soil conservation in developing countries: The case of crop residue mulching. PhD dissertation published by Mansholt Institute, Wageningen, The Netherlands. $286 \mathrm{pp}$.

FAC, 2009. Challenges and opportunities for strengthening farmers organizations in Africa: Lessons from Ethiopia, Kenya and Malawi. Retrieved from www.futureagricultures.org 23rd November 2015.

Fischer, E. and Qaim, M. 2012. Linking smallholders to markets: Determinants and impacts of farmer collective Action in Kenya. World Development 40:12551268.

Francesconi, G. N. and Heerink, N. 2011. Ethiopian agricultural cooperatives in an era of global commodity exchange: does organizational form matter? Journal of African Economies 20(1):153-177.

Jagwe, J.N., Machethe, C.L. and Ouma, E. 2010. Transaction costs and smallholder farmers' participation in banana markets in the Great Lakes Region of Burundi, Rwanda and the Democratic Republic of
Congo. African Journal of Agriculture and Resource Economics 6(1): 302-317.

Jayne, T. S., Mather, D. and Mghenyi, E. 2010. Principal challenges confronting smallholder agriculture in sub-Saharan Africa. World Development 38(10):13841398.

Johnson, N. and Berdegue, J.A. 2004. Collective Action and Property Rights for Sustainable Development. Focus 2 Brief 13 of I6.

Heckman, J. and Vytlacil, E. 2005. Structural Equations, Treatment Effect, and Econometrics Policy Evaluation, Econometrica 73:669-738.

Key, N., Sadoulet, E. and De Janvry, A. 2000. Transactions costs and agricultural household supply response. America Journal of Agricultural Economics 88:245259.

Khandker S.R., G.B. Koolwal and Samad, H.A. 2010. Handbook on impact evaluation: quantitative methods and practices. World. The World Bank, Washington, DC., USA.

Kydd, J. and Dorward, A. 2004. Implications of markets and coordination failures for rural development in least developed countries. Journal of International Development 16:951-970.

Long, J. S. 1997. Regression models for categorical and limited dependent variables. Thousand Oaks, CA: Sage.

Markelova, H., Meinzen-Dick, R., Hellin, J. and Dohrn, S. 2009. Collective action for smallholder market access. Food Policy 34(1):1-7.

Martey, E., Al-Hassan, R.M. and Kuwornu, J.K. 2012. Commercialization of smallholder agriculture in Ghana: A Tobit regression analysis. African Journal of Agricultural Research 7(14): 2131-2141.

Mathenge, M., Place, F., Olwande, J. and Mithöfer, D. 2010. Participation in agricultural markets among the poor and marginalized: Analysis of factors influencing participation and impacts on income and 
poverty in Kenya. Tegemeo Institute. Okello, J. J., Narrod, C. and Roy, D. 2007. Egerton University, Kenya.

Mukundi, E, Mathenge, M. and Ngigi, M. 2013. Sweet potato marketing among smallholder farmers: The role of collective action. Invited paper presented at the 4 th International Conference of the African Association of Agricultural Economists, September 22-25, 2013, Hammamet, Tunisia.

Musyoki, J.K., Mugwe, J., Mutundu, K. and Muchiri, M. 2013. Determinants of household decision to join Community Forest Associations: A case study of Kenya. ISRN Forestry, 2013.

Narrod, C., Roy, D., Okello, J., Avendaño, B., Rich, K. and Thorat, A. 2009. Publicprivate partnerships and collective action in high value fruit and vegetable supply chains. Food Policy 34(1): 8-15.

Nyikahadzoi, K., Siziba, S., Nokoe, S., Njuki, J. and Adekunle, A. 2010. Promoting effective collective marketing in the context of integrated agricultural research for development in Sub Saharan Africa. Learning Publics Journal of Agriculture and Environmental Studies 1 (1): 82 97.

Food safety requirements in African green bean exports and their impact on small farmers. IFPRI discussion paper 00737. Washington, DC., USA.

Olwande, J. and Mathenge, M. 2010. Market participation among poor rural households in Kenya. Tegemeo Institute of Agricultural Policy and Development.

Reardon, T., Barrett, C. B., Berdegue', J. A. and Swinnen, J. F. M. 2009. Agrifood industry transformation and small farmers in developing countries. World Development 37(11):1717-1727.

Rosenbaum, P.R. and Rubin, D. R. 1983. The central role of the propensity score in observational studies for causal effects. Biometetrika 70:41-55.

Valentinov, V. 2007. Why are cooperatives important in agriculture? An organizational economics perspective. Journal of Institutional Economics 3(1):55-69.

Yang, D. and Liu, Z. 2012. Does farmer economic organization and agricultural specialization improve rural income? Evidence from China. Economic Modeling 29:990-993. 